METALLURGY AND FOUNDRY ENGINEERING - Vol. 38, 2012, No. 2

http://dx.doi.org/10.7494/mafe.2012.38.2.109

Beata Leszczyńska-Madej*, Maria Richert**, Teresa Sak***

\title{
EFFECT OF UNCONVENTIONAL METHODS OF CUTTING ON MICROSTRUCTURE, TOPOGRAPHY AND MICROHARDNESS CHANGES IN STEEL
}

\section{INTRODUCTION}

In recent years the requirements for good quality cut surfaces are continuously increasing. If the cut surface does not meet certain requirements, it is necessary to use additional external machining. Moreover, it is necessary, in the aspect of engineering, to keep the dimensions of elements what have contributed to the development of unconventional methods of cutting technology. The main purpose of these technologies is reducing the impact of tools and temperature of the process on the formed surfaces.

One kind of these methods is plasma arc cutting. It involves high-temperature plasma, which is formed between electrodes and cutting materials. That temperature melts or evaporates the material forming kerf. This form of separating is one of the fastest and it is mainly used for metals with high-melting point like pure titanium, for example [1, 2]. Such a high temperature effect on the material in the process (although the time of its operation is very short), very often results in increases of surface hardness in some alloys [3]. Some defects occur on the surface after plasma cutting, but no cracks have been observed. Sometimes, when speed of cutting is too low a quite big amount of dross appears [4].

The second one of unconventional methods is laser cutting, which is undoubtedly one of the most competitive modern technologies used for cutting. It involves the separation of the material by directing a focused laser beam on the material that generates a heat moving the cut edge. However, this method requires using of additional gas, which removes material leading to the formation of kerf [3]. Influence of heat (affected) zone is certainly narrower than it is in the case of plasma cutting. Laser beam is focused in the lens and falls on the surface of the heated material causing the melting or evaporation. This method is

* Ph.D., ** Prof., Ph.D., D.Sc., *** M.Sc.: AGH University of Science and Technology, Faculty of Non-Ferrous Metals, Krakow, Poland; e-mail: bleszcz@agh.edu.pl 
characterized by high corrugation of profile. Comparing both methods, the plasma cutting shows a higher thermal heat affected zone, nevertheless it has a significant impact on the structural changes of the material and its properties such as increase in microhardness due to phase transformation [5].

Belhadj et al. [6] used the laser cutting for electrical steels avoiding the shearing deformation in cutting area and thermal stress in the steels should decrease what limited the harmful effect of these stresses. This method can be also applied to cut the austenitic stainless steel because obtained kerfs are of good quality [7]. Sometimes it is accompanied by the presence of micro-crack, which was examined by Karatas [8] in the laser cut steel. He suggested that the reason for their occurrence was uneven and rapid cooling of the solidified material on the surface, what is not often performed.

The aim of the presented study was to determine the effect of cutting method (plasma arc and laser beam) on the structure and properties changes and to assess the depth of the impact of these changes.

\section{EXPERIMENTAL}

One set of the samples from the same plate was cut with a continous $\mathrm{CO}_{2}$ lasers. Laser beam is generated in resonator where atoms of carbon dioxide are activated. The other set was cut via plasma cutting. In this process, an inert gas is blown at high speed out of a nozzle. At the same time an electrical arc is formed through the gas from the nozzle to the surface being cut, turning some of that gas into plasma. The plasma is sufficiently hot to melt the metal being cut and moves sufficiently fast to blow molten metal away from the cut.

After cutting process, the most representative samples were cut for the investigations.

Macroscopic observations were performed to estimate the quality of the surface samples after cutting process and to determine the effect of cutting process on the roughness of the cut areas. Detailed information about influence of the cutting method on the structure changes provided data from microstructure observation. The samples were cut out and then mechanically ground and polished using diamonds pastes and colloidal suspension of $\mathrm{SiO}_{2}$. The used technique for showing structure and the possible structure changes was etching in the Nital reagent (chemical composition: $95 \% \mathrm{C}_{2} \mathrm{H}_{5} \mathrm{OH}+5 \% \mathrm{HNO}_{3}$ ). The influence of cutting methods on the surface topography after cutting process was carried out using SEM Tesla BS300.

To establish how cutting method influences the properties of the carbon steel, the microhardness was measured on the polished samples, the applied load was 100 G.The measurements were performed several times at different areas, ranging from zone to zone near cutting area into the centre, where the influence of the cutting on the structure and properties was not seen. Zones were called as follows: zone 1, zone 2, zone 3 etc. in the direction of cutting of the material. The scheme of the microhardness measurements is presented in Figure 1. 
a)

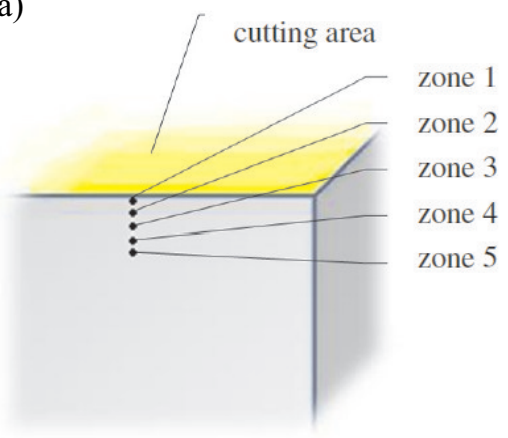

b)

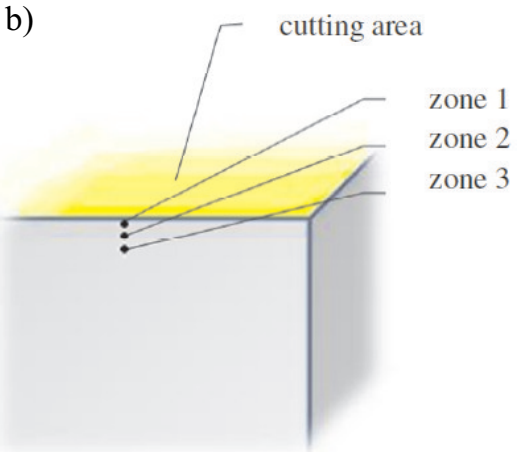

Fig. 1. A scheme showing microhardness measurements of the material: a) cut by plasma; b) cut by laser

\section{RESULTS}

\subsection{Macroscopic observation}

Figure 2 shows macroscopic view of the samples after cutting process. Microscopic observations of the cutting steel surface show irregular profile (Fig. 2a, b). Surface of the laser cutting steel show striation patterns (Fig. 2a). Such appearance may suggest that the molten metal drag away from the kerf.

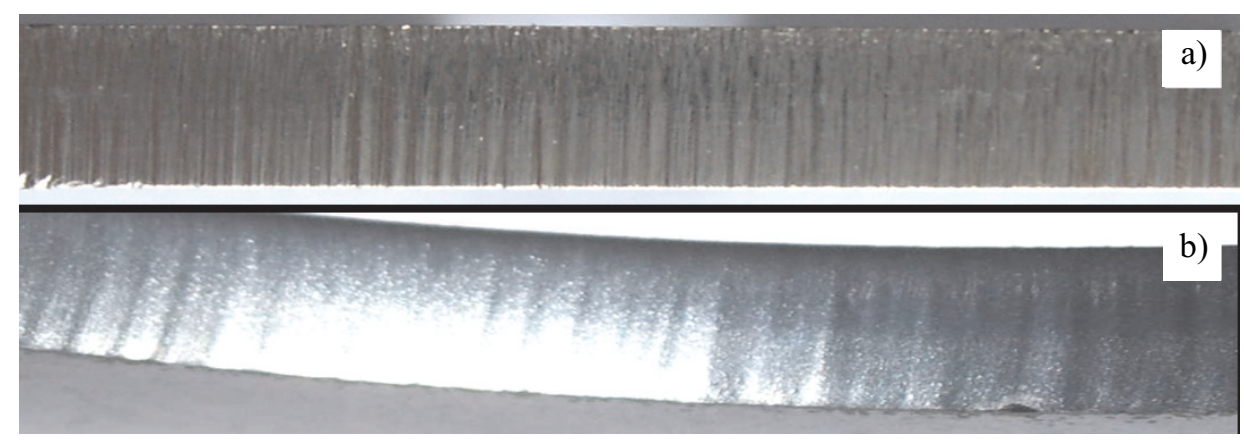

Fig. 2. Macroscopic view of the steel after cutting process: a) by laser; b) by plasma arc

\subsection{Microstructures}

Characteristic microstructures of steel cut by the plasma and laser methods are presented in Figure 3a-d. As it is seen in the figures, after cutting the microstructure of the cut edge of steel was changed. Metallographic etching with Nital solution reveals bainitic structure. The amount of the bainite decreased with increased distance from the edge of the cutting sample. The plasma arc cutting influences structure changes more than laser beam. 
The depth of the structure changes reached an average of $130 \mu \mathrm{m}$ (Fig. 3b) in the case of laser cutting and average of $380 \mu \mathrm{m}$ (Fig. 3d) after plasma cutting. The newly created structure indicates a phase transition arising as a result of warming of the material and its rapid cooling.
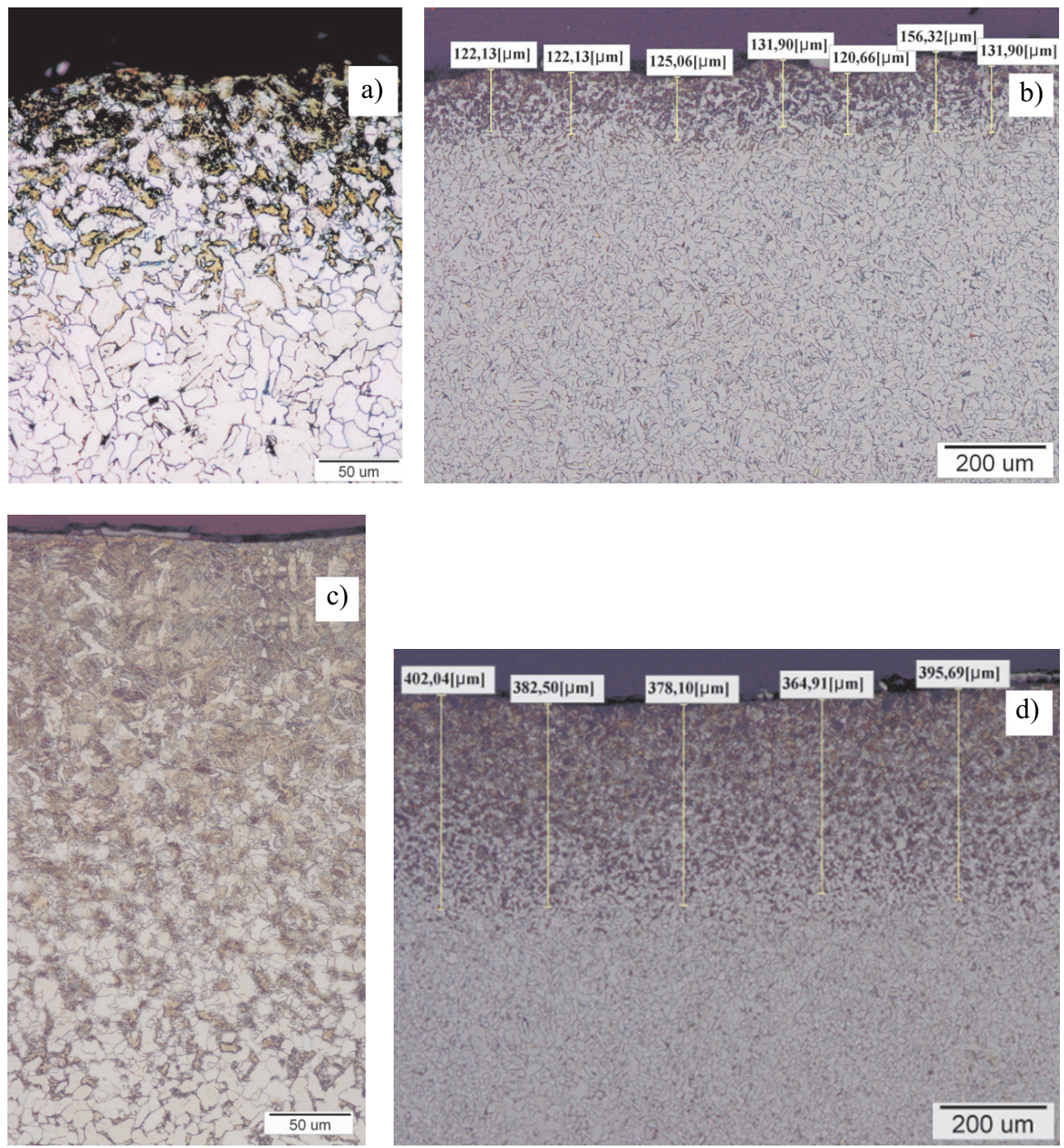

Fig. 3. Microstructures of the cutting steels: $a$, b) by laser; $c$, d) by plasma arc

The performed investigations show that both methods of cutting have a strong influence on the structure and properties of investigated steels, but plasma steel cutting resulted in deeper-reaching changes. 
The laser and plasma affected zone depends on the thermal history that occurs during the cutting process. The effect of materials processing with a laser depends on many factors, which are not easy to control. In cutting most of the laser beam passes through the plate without being absorbed by the work piece or scattered by the plasma [6]. As was proposed by Rosenthal [9] and Duley [10] in the cutting process the energy sent per unit of time comes from the laser beam and from the oxidation reaction. Some part of the formed oxides is removed during cutting process.

\subsection{Topography}

SEM micrographs show large area of the surface smoothness (Fig. 4). In the case of plasma arc cut steel some craters are visible and microcracks on the molten surface (Fig. 4a, b). The main parameter influencing all the aspects related with the plasma surface cut quality is the arc voltage, whereas the cutting speed showed the noticeable effect [4].

After laser cutting, microcracks are also characteristic feature (Fig. 4c, d). The possible sources for cracking are oxides formation on the molten surface and rapid solidification of oxides layer. The thermal expansion and consequent contraction of the surface results in cracks formation. The oxidation reaction on the kerf surface during the cutting process initiates oxygen diffusion into the molten layer [8].
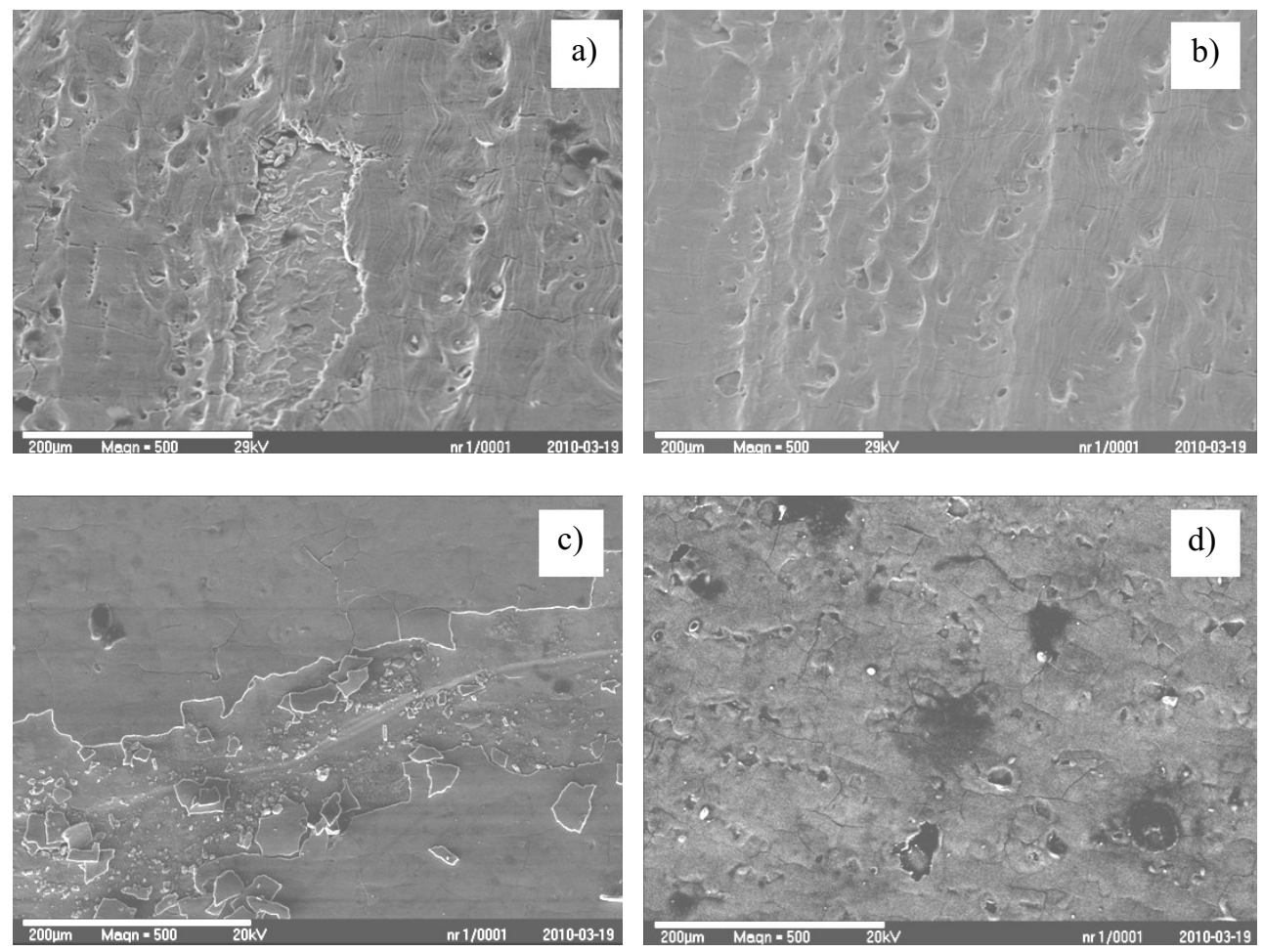

Fig. 4. Topography of the steel cut: $a$, b) by plasma arc; $c$, d) by laser 


\subsection{Microhardness measurements}

Microhardness measurements show, that the microhardness of steel cutting zones increased for both of cutting methods. The measured microhardness near the edge of the cutting was comparable for both processes, about $280 \mathrm{Hv} 0.1$ (table 1, table 2). It was higher about $130 \%$ in comparison to the uncut materials.

Table 1. Microhardness of steel cut by laser

\begin{tabular}{||c|c|c|c||}
\hline \multicolumn{4}{|c|}{ Microhardness of steel cut by laser, Hv0.1 } \\
\hline \multirow{2}{*}{ Aritmetic mean } & Zone 1 & Zone 2 & Zone 3 \\
\cline { 2 - 4 } & 277 & 148 & 117 \\
\hline
\end{tabular}

Table 2. Microhardness of steel cut by plasma arc

\begin{tabular}{||c|c|c|c|c|c||}
\hline \multicolumn{7}{|c||}{ Microhardness of steel cut by plasma, Hv0.1 } \\
\hline \multirow{2}{*}{ Aritmetic mean } & Zone 1 & Zone 2 & Zone 3 & Zone 4 & Zone 5 \\
\cline { 2 - 6 } & 280 & 219 & 173 & 146 & 131 \\
\hline
\end{tabular}

The microhardness changes after cutting process are affected by the phase transformation. In the structure of the steel near the cut surface the bainite was observed.

\section{SUMMARY}

Characteristic microstructure of the steel cut by plasma and laser methods is a bainitic structure. The amount of bainite structure decreased with increased distance from the edge of the cutting sample.

Laser and plasma cutting method resulted in more than twofold increase in microhardness of cutting steel zone with comparison to the microhardness of the uncut material. This is the result of structure changes, which take place under the warming of the material.

The plasma arc cutting influenced structure changes more than laser beam. The depth of the structure changes reached an average of $130 \mathrm{~mm}$ in the case of laser cutting and average $380 \mathrm{~mm}$ after plasma cutting.

\section{Acknowledgements}

The Statutory Activities no 11.11.180.449 supported this work.

\section{REFERENCES}

[1] Klimpel A.: Technologia spawania i cięcia metali. Wydawnictwo Politechniki Śląskiej, Gliwice 1997 (in Polish)

[2] Gariboldi E., Previtali B.: Journal of Materials Processing Technology, 60 (2005), 77-89 
[3] Oczoś K.: Ksztaltowanie materiałów skoncentrowanym strumieniem energii, Redakcja Wydawnictw Uczelnianych Politechniki Rzeszowskiej, Rzeszów, 1988 (in Polish)

[4] Bini R., Colosimo B.M., Kutlu A.E., Monno M.: Journal of Materials Processing Technology, 196 (2008), 345-355

[5] Zaborowski T., Wieczorowski K.: Warstwa wierzchnia kształtowana podczas cięcia materiałów metodami niekonwencjonalnymi. Niekonwencjonalne metody przecinania materiałów konstrukcyjnych, Ogólnopolskie Seminarium Naukowe, Gorzów Wlkp.-Poznań, Wydawnictwo IBEN Gorzów Wlkp. 1984, druk: Edytor Gorzów Wlkp., 1994, 5-33 (in Polish)

[6] Belhadj A., Baudouin P., Breaban F., Deffontaine A., Dewulf M., Houbaert Y.: Journal of Magnetism and Magnetic Materials, 256 (2003), 20-31

[7] Abdel Ghany K., Newishy M.: Journal of Materials Processing Technology, 168 (2005), 438-447

[8] Karatas C., Keles O., Uslan I., Usta Y.: Journal of Materials Processing Technology, 172 (2006), 22-29

[9] Rosenthal D.: Welding Journal, 20 (1941) 5, 220-234

[10] Handbook of Metalforming Process, Edited by H.E. Theis, Marcel Dekker, Inc, New York, 1999

Received

November 2012 